Just Greasing the Wheels?

Mediating Difference or the Evasion of Power and Responsibility in Diplomacy

Adler-Nissen, Rebecca

Published in:

The Hague Journal of Diplomacy

DOI:

10.1163/1871191X-12341303

Publication date:

2015

Citation for published version (APA):

Adler-Nissen, R. (2015). Just Greasing the Wheels? Mediating Difference or the Evasion of Power and Responsibility in Diplomacy. The Hague Journal of Diplomacy, 10(1), 22-28. [5].

https://doi.org/10.1163/1871191X-12341303 


\title{
Just Greasing the Wheels? Mediating Difference or the Evasion of Power and Responsibility in Diplomacy
}

\author{
Rebecca Adler-Nissen \\ Associate Professor, Department of Political Science, University of \\ Copenhagen, Copenhagen, Denmark \\ RAN@ifs.ku.dk
}

We traditionally see diplomats as mediators. They build bridges between nations and they repair them when they break. During a crisis, diplomats 'keep it cool' and try to prevent the crisis from worsening into armed conflict. Diplomats are the men and women who keep the international system running despite its fundamentally conflictual nature. At least, this is how diplomats have portrayed their profession for hundreds of years. This role as mediator is apparent in third-party mediation such as us President Jimmy Carter's involvement in the Israel-Palestine negotiations in 2002-2003 or in the EU's proposal to delegate high-level mediators for talks between President Viktor Yanukovich and the opposition in Ukraine before Crimea was annexed by Russia in March 2014. Explicit mediation is also evident in preventive diplomacy, such as the UN's peacekeeping missions in Macedonia. In both third-party diplomatic mediation and preventive diplomacy, crisis or conflict resolution is the explicit goal.

However, the focus of this contribution is how diplomacy in general is seen as mediating among states, peoples and ideas - and why this is an incomplete view. From James Der Derian's understanding of diplomacy as 'the mediation of estrangement', ${ }^{1}$ over English School-inspired pluralists such as Paul Sharp, ${ }^{2}$ to Costas Constantinou's post-structuralist call for humanism, ${ }^{3}$ diplomacy is seen as the practice of dealing with difference. While there are different interpretations of what that entails, Iver B. Neumann's description of diplomacy as a third culture - that is, a culture for mediation between political entities with diverse cultures — has been widely accepted. ${ }^{4}$

1 James Der Derian, On Diplomacy: A Genealogy of Western Estrangement (Oxford: Blackwell, 1987).

2 Paul Sharp, Diplomatic Theory of International Relations (Cambridge: Cambridge University Press, 2009).

3 Costas M. Constantinou, 'Between Statecraft and Humanism: Diplomacy and Its Forms of Knowledge', International Studies Review, vol. 15, no. 2, 2013, pp. 141-162.

4 Iver B. Neumann, 'To Be a Diplomat', International Studies Perspectives, vol. 6, no. 1, 2005, p. 72. 
Yet as most diplomatic scholars also recognize, diplomacy has never been just about representation and the mediation of difference. It has always been deeply embedded in other international practices. ${ }^{5}$ Diplomacy sometimes produces crises, fuels wars and deepens conflicts. For instance, the Eu's ongoing attempts to stabilize its Eastern neighbours may sometimes result in more instability, rather than less. When the EU sought to reach an association agreement with Ukraine in 2014, it was not just an attempt to form closer ties and promote European standards, values and interests, for according to critics it also alienated Russia-oriented Ukrainians and provoked Russia.

Moreover, diplomats often transgress from their own ideals about representing and mediating between sovereign states. Today, diplomats are working on a myriad of projects of transnational and global governance. While many observers have warned against this development from system maintenance to governance, they tend to hold on to the assumption that diplomacy itself is a politically 'empty practice', or, to use the words of us Ambassador Henry White (1850-1921), diplomats are simply 'greasing the wheels'. ${ }^{6}$ This short contribution is therefore concerned with the way in which scholarly understandings of diplomacy as the mediation of estrangement raise — but also evade — questions of power and responsibility.

\section{Mediation: Diplomats as Custodians of International Society}

Diplomatic studies are still dominated by Hedley Bull's idea of great powers being 'custodians of international society'. A custodian has the responsibility to look after something, a museum, a culture, or a tradition. Clearly, a custodian does not change the exhibitions or the museum as a whole; he or she mainly keeps things in order. While the focus on care-taking corresponds to the self-understanding of many diplomats, it also prevents us from addressing diplomacy's implications in time of crisis.

5 See Rebecca Adler-Nissen, 'Conclusion: Relationalism or Why Diplomats Find IR Theory Strange', in Iver B. Neumann, Ole Jacob Sending, Vincent Pouliot and Iver B. Neumann (eds.), Diplomacy: The Making of World Politics (Cambridge: Cambridge University Press), forthcoming.

6 Henry White et al., 'The Organization and Procedure of the Third Hague Conference', Proceedings of the American Society of International Law at Its Annual Meeting, vol. 6, 1912, p. 182.

7 Hedley Bull, The Anarchical Society: A Study of Order in World Politics (Basingstoke: Palgrave, 1977), p. 13 . 
The diplomatic self-understanding as custodian and mediator - rather than policy-producer - can have almost perverse effects. I recall a discussion in the Danish Ministry of Foreign Affairs (MFA) on the EU's response to the refugee crisis following the international intervention in Libya in March 2011. ${ }^{8}$ I was working in the MFA when the Arab Spring erupted (although it was not called 'Arab Spring' internally in the Ministry, because everybody was aware of the important differences between the processes in the different North African countries). Whereas the Ministry of Refugee, Immigration and Integration Affairs mentioned the possibility of a review of visa possibilities for selected groups of refugees from Libya, the MFA concentrated on finding a position that could balance domestic concerns and the median position among the EU member states - our partners. When I asked for clarification of the MFA's own position on the refugee crisis, the response from my superior was that 'we follow governmental policy'. But the governmental policy had yet to be defined and the MFA was a party to the negotiations on how to handle the refugee situation. In the end, the Danish Foreign Minister was equipped with the following speech note for the EU's Foreign Affairs Council meeting:

- We support that the general visa dialogue continues with southern neighbours.

- It is still too early to consider negotiations on visa facilitation and visa liberalization.

So we just went with the flow. This positioning is illustrative of how small states experience themselves as minor players and system maintainers. It is, however, also a very comfortable position, because one can pretend that one is not taking sides in a conflict or crisis.

Diplomatic scholars are aware that while diplomacy successfully mediates differences, it does not necessarily address root causes of a crisis (it may sometimes even prolong it). Arguments range from accepting and perhaps even endorsing that diplomacy is pragmatic system maintenance to more idealistic attempts to sustain 'global hope' and 'restore diplomacy as a virtue. ${ }^{9}$ For the functionalists Martin Hall and Christer Jönsson, 'diplomacy can be analysed

8 This anecdote also figures in Adler-Nissen, 'Conclusion: Relationalism or Why Diplomats Find IR Theory Strange', forthcoming.

9 Costas M. Constantinou and James Der Derian, 'Sustaining Global Hope: Sovereignty, Power and the Transformation of Diplomacy', in Costas M. Constantinou and James Der Derian (eds), Sustainable Diplomacies (Houndmills: Palgrave Macmillan, 2010), p. 3. 
as the mediation of universalism and particularism'.10 Somewhat similarly, Ole Jacob Sending and Iver B. Neumann argue that diplomacy 'derives its strength in part from allowing disagreement and contestation, also over the appropriate form and content of diplomacy in different situations.'11 Most explicitly, Paul Sharp insists on diplomacy retaining separateness, whether between entities, individuals, cultures or states. Indeed, Sharp sees 'diplomacy as a way of conducting relations not just between sovereign states, but also between other groups of people who regard themselves as distinctive and value their independence..12 This emphasis on accepting differences and mediating otherness is a consequence of seeking to 'rescue' diplomacy from being mere foreign policy implementation, ${ }^{13}$ but it also risks turning our attention away from questions of political responsibility and leadership.

\section{Diplomats, Governance and Political Responsibility}

The argument about diplomacy's ability to mediate distinct ideas or world visions is not incorrect, but it is incomplete. Mediation has been codified in procedures and protocol over hundreds of years. It is also important for how diplomats approach crisis situations, as Us Ambassador White's reflections from the beginning of the twentieth century illustrate. Ambassador White participated in the Algeciras Conference in 1906, which addressed the Tangier crisis (where Germany attempted to prevent France from establishing a protectorate over Morocco). The chief concern of most delegates was that the conference should not disband without an agreement, as this would possibly lead to war. The ambassador reported:

I felt at the time, and have felt ever since, that it was owing to the perpetual exchange of views which took place day after day between the delegates outside the conference $[. .$.$] that all friction at the formal sessions$

10 Christer Jönsson and Martin Hall, Essence of Diplomacy (Houndmills: Palgrave Macmillan, 2005), p. 25 .

11 Ole Jacob Sending and Iver B. Neumann, 'Banking on Power: How Some Practices in an International Organization Anchor Others', in Emanuel Adler and Vincent Pouliot (eds), International Practices (Cambridge: Cambridge University Press, 2011), p. 236.

12 Paul Sharp, 'Herbert Butterfield, the English School and the Civilizing Virtues of Diplomacy', International Affairs, vol. 79, no. 4, 2003, p. 874.

13 The author thanks Costas Contantinou for this point. 
was avoided, in spite of an amount of tension in the atmosphere prevalent almost to the end..$^{14}$

For diplomats, 'the perpetual exchange of views' is thus crucial. A crisis, conflict or a war does not mean that diplomacy stops offering a language for the mediation of estrangement. Diplomacy is concerned with the management of relations (be they hostile or amicable). This continuous and reflexive focus on difference is perhaps what sets diplomacy apart from other practices in world politics.

However, this focus also implies that diplomats are cast as messengers and that the message is developed somewhere else and by someone else (for example, the government or the foreign minister). The mediation idea is based on a fiction of a politically empty practice of delivering messages and exchanging views. This fiction, of course, is necessary for the performance of most forms of diplomatic negotiations, but it does not always have the kind of social backing that diplomatic scholars implicitly assume. Much of what is promoted as national interests is never discussed among government ministers or in parliamentary assemblies. Diplomats, in other words, also produce policy by themselves.

This was also the case a century ago when Ambassador White represented the United States in the International Agriculture Conference in 1905. This conference:

$[\ldots]$ assembled not only with a very vague idea as to what shape, if any, its labors would assume, but with a strong conviction on the part of a majority of the delegates that no result at all was likely to be attained, beyond perhaps a demonstration of good will to the Italian sovereign and nation. ${ }^{15}$

However, as a result of the 'zeal and tact of the very able men composing the Italian delegation, encouragement and interest took the place of skepticism and apathy'16 In the end, the negotiations that started with 'very vague ideas' led to the sharing of information on agricultural products and the establishments of agricultural bureaus across much of the Western world. The ambassadors not only exchanged views, they helped produce the positions of their nations.

14 White, 'The Organization and Procedure of the Third Hague Conference', pp. 183-184 [my italics].

15 White, 'The Organization and Procedure of the Third Hague Conference', p. 181.

16 White, 'The Organization and Procedure of the Third Hague Conference', p. 181. 
The distinction between diplomatic mediation and political power becomes even more untenable when we look at how diplomacy works today. Diplomacy not only involves the representation of particular interests, but also the construction of a more integrated international order - a 'common lifeworld'.17 Multilateralism has become a dominant form of diplomacy that often transgresses from the positions of separate states and legitimizes international interventions in the United Nations Security Council. ${ }^{18}$ National diplomats today are deeply engaged in the construction of the EU's common foreign and security policy, military capacity-building and the development of a common diplomatic service. ${ }^{19}$ To counter such developments towards global governance, which challenges traditional sovereignty, Paul Sharp proposes that political leaders should be 'surrounded by virtuous advisers and agents embodying and advocating the values of diplomacy'. ${ }^{20}$ Yet, as Sharp also acknowledges and as Weber pointed out decades ago, ${ }^{21}$ those 'values of diplomacy' have never fully reflected the practice of diplomacy.

Diplomatic studies should therefore avoid uncritically overtaking diplomats' self-understanding as mediators. First, diplomats have never been simply custodians of international society; they inevitably take sides, even when they pretend not to do so. Diplomats have both helped solve and produce conflicts around the world. Diplomats are political both when they follow instructions and when they write them themselves.

Second, deepening economic, cultural and political connections across national borders have transformed the international state system into a global web of relations. System maintenance has evolved to governance, partly under the radar of public attention, yet diplomats still pass as messengers. Diplomacy is still focused on living together in difference, but this life together - in its multilateral, networked forms - has become increasingly demanding for all of the parties involved. To say that diplomacy is concerned with the mediation of estrangement is therefore only to tell part of the story.

17 Corneliu Bjola, 'Legitimating the Use of Force in International Politics: A Communicative Action Perspective, European Journal of International Relations, vol. 11, no. 2, 2005, p. 279.

18 Rebecca Adler-Nissen and Vincent Pouliot, 'Power in Practice: Negotiating the International Intervention in Libya', European Journal of International Relations, 2014.

19 Rebecca AdlerNissen, 'Symbolic Power in European Diplomacy: The Struggle between National Foreign Services and the Eu's External Action Service', Review of International Studies, 2013, available on CJO 2013 doi:10.1017/So260210513000326.

20 Sharp, 'Herbert Butterfield, the English School and the Civilizing Virtues of Diplomacy', p. 875 .

21 Cynthia Weber, 'Reconsidering Statehood: Examining the Sovereignty/Intervention Boundary', Review of International Studies, vol. 18, no. 3, 1992, pp. 199-216. 
Rebecca Adler-Nissen is Associate Professor in the Department of Political Science at the University of Copenhagen. Her research focuses on international relations theory, diplomacy, sovereignty and European integration. She is former Head of Section in the Department of European Policy at the Danish Ministry of Foreign Affairs. Adler-Nissen is the author of Opting Out of the European Union: Diplomacy, Sovereignty and European Integration (Cambridge: Cambridge University Press, 2014). 